\title{
PRÁTICAS NO ENSINO DE FILOSOFIA: FILOSOFANDO COM A TRADIÇÃO E COM STAR TREK DEEP SPACE NINE NA SALA DE AULA
}

\author{
Valéria Cristina Lopes Wilke*
}

\begin{abstract}
Resumo: Discutir a potencialidade imagem em movimento no ensino de Filosofia e a compreensão do filme como discurso significante, conjugando as experiências desenvolvidas em pesquisas e sala de aula. Apresentar também recortes de disciplina ministrada que utilizou textos filosóficos e episódio de StarTrek Deep Space Nine. O filme é entendido como texto filmico, um objeto em cuja materialidade estão inscritos diferentes códigos da linguagem cinematográfica, e como documento informacional, que comporta diferentes níveis de informações que necessitam ser reconhecidas e trabalhadas, a fim de que o uso pedagógico seja satisfatório. Assim, para além do entretenimento, o texto fílmico tem a possibilidade de ser usado como recurso pedagógico e de análise social. Observa-se como constitutivos do universo Trek os filmes realizados para o cinema e as séries televisivas.
\end{abstract}

Palavras-chave: Texto Filmico; Ficção Científica; Star Trek - Deep Space Nine, Pedagogia da Imagem; Alteridade.

Resumen: Presentar la imagen potencial en movimiento en la enseñanza de la filosofía y la comprensión de la película como un discurso significativo, basado en la experiencia desarrollada en la investigación y en el aula. También presentar aspectos del desarrollo de la disciplina que se enseña usando textos filosóficos y un episodio de Star Trek Deep Space Nine. La película se entiende como texto fílmico, un objeto en cuya materialidad se insertan diferentes códigos que funcionan en el lenguaje cinematográfico, y también como un documento informativo, que llevan diferentes niveles de información y que necesitan ser reconocidos y trabajados, para que el uso pedagógico sea satisfactorio. Además del entretenimiento, el texto fílmico tiene la posibilidad de ser utilizado como recurso pedagógico y educativo y análisis social. Las películas hechas para cine y series de televisión se consideran constitutivas del universo Trek.

Palabras claves: Texto Fílmico; Ciencia Ficción; Star Trek - Deep Space Nine; Pedagogía de la imagen; Otredad.

\section{Introdução}

O uso recorrente da imagem em movimento na minha prática docente suscitou questões, as quais conduziram ao desenvolvimento de sucessivas pesquisas ${ }^{2}$ que abor-

\footnotetext{
" Professora Associada do Departamento de Filosofia - Universidade Federal do Estado do Rio de Janeiro E-mail: valeria.wilke@unirio.br.

${ }^{2}$ Essas pesquisas foram realizadas em parceria com a Profa. Dra. Carmen Irene Correia de Oliveira (Departamento de Ciências Sociais) e Profa. Dra. Leila Beatriz Ribeiro (Departamento de Processos-Técnicos Documentais), ambas da Universidade Federal do Estado do Rio de Janeiro/UNIRIO.
}

daram especialmente a potencialidade imagem em movimento no processo de ensinoaprendizagem e a percepção do filme como discurso significante. $\mathrm{O}$ caminho percorrido por essas investigações conduziu à elaboração de método analítico do filme como texto fílmico e como documento informacional, no contexto da prática pedagógica. Motivada pela larga experiência no emprego dessa maneira de lidar com filmes em disciplinas de teor filosófico, o objetivo nesse artigo é

WILKE, Valéria Cristina Lopes. Práticas no ensino de filosofia: filosofando com a tradição e com Star Trek Deep Space Nine na sala de aula. Revista Sul-Americana de Filosofia e Educação. Número 34: nov. 2020 - abril 2021, p. 159-177. DOI: https://doi.org/10.26512/resafe.v2i34.35138 
apresentar recortes de como esse tipo de pedagogia da imagem pode ser utilizado na prática de ensino da filosofia. ${ }^{3}$ Nesse sentido, serão delineados alguns aspectos teóricos que embasam o modo como são debatidos temas com estudantes, a partir da utilização de textos filosóficos e textos fílmicos.

No desenvolvimento da indústria cultural, as experiências de entretenimento e a pedagógica de produtos que utilizam a imagem em movimento foram expandidas $e$ igualmente, contribuíram para a ampliação da compreensão do cinema enquanto indústria: nas últimas décadas, filmes e séries televisivas passaram a ser produzidos diretamente para as empresas de online streaming on demand (transmissão online sob demanda) $e$ para os canais a cabo. Tal situação se insere nas ponderações feitas por Jenkins (2009) quanto ao que ele nomeou como era da convergência ${ }^{4}$, pois nesse contexto o formato

${ }^{3}$ Esse artigo é resultado de comunicação apresentada no VI Encontro do GT Filosofar e Ensinar a Filosofar (2019 - UFMA)

4 Segundo Jenkins (2009), convergência é o termo que melhor define as transformações antropológicas, tecnológicas, culturais, industriais, mercadológicas $e$ sociais que atravessam a maneira como as mídias circulam na cultura atual. Cada novidade tecnológica e/ou cada nova forma de consumo de um conteúdo implica a adaptação no processo da convergência. Por exemplo, inicialmente o celular foi usado somente como telefone móvel; hoje é um aparato em que se assiste séries, filmes e até estuda-se, e também produz e envia conteúdos. No contexto da convergência o fluxo de conteúdos escorre por múltiplas plataformas $e$ formatos midiáticos, promovendo a interligação de múltiplos mercados de mídias, o trânsito migratório frenético do público dos meios de comunicação de uma mídia para outra, de uma plataforma para outra, e novas formas de interação e apropriação dos conteúdos pelos públicos, que afetam o próprio modus operandi da produção midiática. O tripé que sustenta a argumentação de Jenkins é formado por três conceitos fundamentais: a convergência midiática como processo cultural e não tecnológico, que favorece a das séries televisivas extrapolou as redes de televisão devido ao crescimento dos serviços de vídeo on demand (VOD), como Netflix e Hulu, por exemplo, empresas provedoras de filmes, documentários, séries, animações que passaram também a produzir e fornecer conteúdos originais e não apenas reproduzir os realizados por outrem. As séries atuais deixaram para trás os pioneiros seriados televisivos que estão na sua origem, como Papai sabe tudo, Bonanza, Dr. Kildare ou Star Trek - série clássica, uma vez que elas sofreram significativas mudanças quanto ao conteúdo, forma de produção, público, alcance, veiculação consumo e importância, muito em função das tecnologias digitais e da internet que as tornaram crescente fenômeno global.

Em que pesem as diferenças entre uma série e um filme, especialmente as relacionadas à repetição de personagens, situações, temas e leitmotiv, presentes na primeira, ambos produtos são narrativas construídas com a linguagem cinematográfica aplicada à imagem em movimento. Esse aspecto faz com que considere como constitutivo do universo Star Trek tanto os filmes realizados para as salas de cinema como as sucessivas séries televisivas, hoje acessíveis pela TV a cabo e pelas empresas de streaming.

Para a comunicação do entrelaçamento possível da tradição filosófica com o texto fílmico serão apresentados aspectos da atividade realizada em que foram conjugadas a narrativa sci-fi do universo Trek (epi-

narrativa transmidiática; o predomínio da inteligência coletiva que congrega a experiência de diferentes indivíduos de uma audiência e que se opõe ao paradigma do expert, e a cultura participativa do consumidor que interage com o complexo sistema de produção, no âmbito da economia afetiva. 
sódio "Dueto" da série Deep Space Nine) e reflexões filosóficas acerca da política e da alteridade considerando-se dois ensaios de Montaigne e o conto filosófico de Voltaire, Micrômegas, para a reflexão sobre o encontro com o outro, tendo como solo provocador aberto pelo conceito de colonialidade de Aníbal Quijano.

Para tanto, em primeiro lugar, fornecerei a concepção de textos fílmicos que embasa meu trabalho em sala de aula, que pode ser aplicada às séries televisivas de ficção científica. Ou seja, cada episódio é entendido também como um texto filmico, que agencia distintas informações e modos de lêlas. A seguir, discorrerei sucintamente sobre o gênero de ficção científica e, finalmente, sobre aspectos de uma discussão realizada sobre o encontro com o outro em que foram utilizados textos filosóficos e um episódio de Deep Space Nine, que pode servir como documento para análise de questões contemporâneas relacionadas à política $e$ à tecnologia. Ao longo desse percurso, terei indicado, portanto, algumas linhas mestras adotadas na construção de disciplinas em que utilizo a imagem em movimento.

\section{Para entender o texto filmico - aspectos es- senciais}

Minha prática docente tem sido pontuada pelo uso da imagem (seja a fixa, seja em movimento), o que me levou a sucessivas pesquisas institucionais ${ }^{1}$ sobre a potencialidade pedagógica da imagem, do cinema $e$ do filme, como uma de suas materializações, como portadores de significações.

O filme é imagem em movimento e, nas disciplinas em que abordo seu uso pe- dagógico, a natureza desse tipo de imagem é discutida mediante a noção de tecnoimagem formulada por Flusser (2002, 2010), i.e, aquela mediada por aparelhos. Para esse filósofo, a imagem é superfície e também um tipo de abstração que, por seu caráter representacional, tornou-se o instrumento básico para desmaterializar corpos e coisas. No processo de hominização, inicialmente o conhecimento foi adquirido por meio do contato inicial e do embate com o mundo físico $e$, pouco a pouco, foi crescendo em abstração a partir da possibilidade de representar $\mathrm{o}$ mundo. A apreensão do mundo pelo ser humano, portanto, foi se afastando da realidade natural com o começo da produção das imagens, as quais expressam a capacidade imaginativa humana de criar figuras iconográficas para re-apresentar o mundo. Essa criação imagética resulta da abstração de duas das quatro dimensões espaço-tempo e é a imagem tradicional aquilo que aparece chapada nas dimensões do plano. Posteriormente, a escrita foi inventada mediante a abstração de mais uma dimensão espacial, o que ampliou a relação abstrata com a realidade. A escrita introduziu uma nova temporalidade, a linear, contínua e causal - porque o código somente é entendido com a ordenação dos símbolos, que são lidos na sequência linear a partir de uma gramática - $e$ também uma nova consciência, a histórica. $\mathrm{Na}$ continuidade do processo de hominização, no contexto da revolução industrial $e$ do moderno progresso das forças produtivas, tornou-se possível o aparecimento das imagens técnicas, aquelas mediadas pelos aparelhos. A imagem fotográfica e a cinematográfica são exemplos da imagem técnica. 
O cinema é discutido, por sua vez, como uma produção cultural eminentemente da modernidade, nascida no contexto do desdobramento das forças produtivas no século XIX e da indústria cultural que se anunciava. Ele é marcado pela expectativa do progresso científico no âmbito dos avanços técnicos necessários para a construção da linguagem cinematográfica, e também no nível da elaboração e aperfeiçoamento das narrativas fílmicas. A linguagem cinematográfica implicou o estabelecimento de um complexo sistema de códigos que demandou o aprendizado do espectador e do realizador, a fim de que a diegese pudesse ser compreendida. $\mathrm{O}$ momento inicial dessa linguagem caracterizou-se pela imobilidade da câmera diante de algum evento que seria registrado $e$ as obras dos irmãos Lumière, nos fins do século XIX, são exemplos desta fase. George Meliès, contemporâneo dos Lumière, foi o primeiro a construir uma estrutura narrativa e a editar uma história, fato que abriu as possibilidades de rearranjar as sequências na tela. Como informou Carriére (1995), a linguagem cinematográfica foi criada quando os cineastas aprenderam a cortar o filme em cenas, e depois a montá-lo e a editá-lo, num processo contínuo de aperfeiçoamento que elaborou o vocabulário e a gramática cinematográficos. Desses pioneiros para cá, mais códigos da linguagem cinematográfica e da narrativa fílmica foram estabelecidos e desenvolvidos, tal como atesta a história do cinema.

No escopo das pesquisas realizadas $e$ da minha prática docente, por um lado, o filme tem sido considerado como um elemento do cinema, e esse tomado, por sua vez, como fenômeno muito mais amplo que precede e sucede a produção de um determinado filme. Ele é compreendido aqui como um sistema complexo que envolve a indústria cultural e seus produtos (o texto fílmico, a publicidade que o cerca, o merchandising, a caneca, os bonecos, os parques temáticos de estúdios cinematográficos, por exemplo) e que abrangeria todo um conjunto de eventos que precede (infraestrutura econômica da produção, os estúdios, as legislações nacionais, papel da censura), e sucede a produção do filme (influência sociocultural, política e ideológica do filme, o ato de assistir ao filme numa sala de exibição ou em casa, a disponibilidade das salas para exibição, etc).

Por outro lado, o filme, no âmbito das investigações foi avaliado como um texto filmico (Wilke, Oliveira, Ribeiro, 2007, 2003, 2001): um objeto delimitável, o filme, que materializa um discurso significante, qual seja, o discurso cinematográfico, que comporta, por sua vez, diferentes códigos cinematográficos (por exemplo, o movimento da câmera, as grandes panorâmicas, os diferentes planos) e não-cinematográficos (por exemplo, o código de honra nos filmes de guerra ou no western). Por conseguinte, ele necessita ser compreendido dentro da circunstância que abrange a produção cinematográfica e seus códigos, e também da própria delimitação do que vem a ser um texto, tal como produzido em qualquer linguagem. Essa compreensão me conduziu à abordagem, em sala de aula, do filme como texto que implicou explorá-lo, junto com os estudantes, como objeto permeado de significados que precisa ser "[...] apreendido, entendido e interpretado pelo sujeito a partir das informações que o estruturam internamente 
$e$ daquelas que o reinserem no contexto de produção. [...]". (WILKE, OLIVEIRA, RIBEI$\mathrm{RO}, 2007, \mathrm{~s} / \mathrm{p})$

$\mathrm{O}$ resultado dessas pesquisas gerou um modelo analítico-interpretativo do texto fílmico, elaborado após a formulação de questões teórico-metodológicas que conduziram a investigação acerca do uso de filmes na prática pedagógica. Na trajetória histórica da compreensão do filme, devedora da ampliação do entendimento de documento ${ }^{5}$, o texto fílmico foi tomado como documento informacional: como um espaço de inscrição onde as informações dão forma a conteúdos que podem, mediante análise, oferecer representações constitutivas de uma memória ${ }^{6}$ ou de projetos de memória e de projetos identitários concebidos pela sociedade (contexto) que o produziu. O modelo criado opera a partir da concepção do que foi conceituado como informações intradiscursivas $e$ extradiscursivas, que funcionam, por sua vez, como níveis explicativos do filme. Esses

\footnotetext{
${ }^{5}$ No campo da História vimos o aparecimento da Escola dos Annales, na década de 1930, que introduziu mudanças sensíveis na compreensão do que vem a ser a História e também o documento. Posteriormente, o historiador Marc Ferro foi um dos pioneiros a incorporar o cinema (logo, o filme) como fonte histórica para o entendimento do mundo, uma vez que as crenças, as intenções, o imaginário são História tanto quanto o documento escrito. Nesse sentido, por mais despretensioso um filme pareça ser, ele expressa os aspectos de uma época por meio de suas imagens, de seu roteiro, enfim, do modo como a linguagem cinematográfica foi articulada.

${ }^{6} \mathrm{O}$ texto fílmico possui também dimensão memorial, pois a memória trabalha seletivamente arregimentando os elementos, os acontecimentos que constituirão "aquilo que fica e que vale" para aquele grupo no qual ela se constrói, para uma determinada época. Esta situação também vale para o filme.
}

níveis informacionais são agenciados pelos leitores durante a leitura do texto fílmico.

No processo de significação os espectadores necessitam poder ler os códigos presentes na produção desse tipo de texto, os cinematográficos e não-cinematográficos, os quais foram denominados como informações intradiscursivas. Essas somente serão lidas e significadas à medida que os espectadores/leitores consigam decifrá-las nos códigos em que estão inscritas e que constituem o texto fílmico. Na nossa cultura imagética, o aprendizado desses códigos é desenvolvido de maneira que aparenta até ser natural, mas que é cultural. Por conseguinte, é admitido que os espectadores (os leitores de texto filmico) detêm um conhecimento mínimo para acompanhar uma trama cinematográfica. Estão situadas ainda neste conjunto de códigos as informações ligadas à feitura do filme enquanto película (uso de todos os artefatos da indústria cinematográfica), assim como a elaboração do filme sob o aspecto dramatúrgico (direção, atuação, construção de roteiro, escolha da trilha sonora, etc). Cada espectador/leitor, segundo seu capital cultural, pode localizar os elementos discursivos pertinentes para obter um entendimento mais ou menos elaborado das estratégias escolhidas por quem produziu e realizou o filme

Além das intradiscursivas, foi percebido também que havia outro patamar de significação, aquele compreendido pelas informações extradiscursivas, que seriam as chaves de leitura que os receptores acionariam, a partir dos mecanismos fornecidos pela inserção social, para ler a realidade construída cinematograficamente. Assim, na dinâmica da leitura do texto filmico há as informações 
externas que não estão inscritas nesse tipo de documento, mas que são acionadas por serem circulantes e/ou potencialmente latentes nos contextos de inserção do receptor. Ou seja, as informações intra e extra discursivas que estão entrelaçados na construção da dramaturgia fílmica precisam ser minimamente compreendidas para que o texto fílmico possa ser explorado como algo mais do que mero recurso didático que exemplifique uma certa situação do mundo real. Muitas vezes o trabalho com o filme de ficção em sala de aula mostrou que ele pode se tornar empobrecido devido à incapacidade de o espectador/leitor ultrapassar os limites que a não-compreensão da linguagem cinematográfica impõe, seja pela utilização inadequada seja pela ausência de leitura crítica.

Um terceiro grau de significação foi identificado também, qual seja, o espaço de ação em que apareceriam novas discursividades elaboradas a partir da interação entre os espectadores/leitores, o contexto da sala de aula e o da produção do texto fílmico. Nele desaguariam os acionamentos anteriores para a produção de novas discursividades e que constituiriam novos ambientes de interlocução e de negociação de sentido, em sala de aula, e que produziriam, em decorrência, a materialização de novos textos. Este espaço apresenta-se como o locus, por excelência, da relação pedagógica em que o estudante/espectador/leitor e o docente/espectador/leitor produzem novos sentidos.

As pesquisas resultaram também na elaboração de um instrumento analítico, a Ficha Descritivo-Analítica, que é a ferramenta que permite o registro das informações intra e extradiscursivas ${ }^{7}$. Esse dispositivo contribui para que o texto fílmico não seja utilizado como mera ilustração do conteúdo trabalhado a partir de textos ficcionais e/ou acadêmicos. Minha prática docente tem mostrado que o preenchimento dos campos da ficha pelos estudantes contribui para a leitura crítica do texto fílmico, porque ela funciona de maneira análoga ao de um fichamento de texto não imagético, que é instrumento fundamental para a sua compreensão e aporte essencial para a discussão em sala de aula.

\section{A ficção científica como gênero}

Após discutir a imagem e o texto fílmico, em disciplinas que trabalho com obras de ficção científica passo a abordar a ficção científica.

Deve-se à revolução industrial, no século XIX, a grande visibilidade que a ciência moderna e seus produtos adquiriram. Esta situação fez com que inicialmente obras literárias e, posteriormente, fílmicas incorporassem temáticas e questões oriundas do contexto científico-industrial, que abriu o horizonte para se sonhar com o futuro.

A ficção científica pode ser considerada um subgênero da ficção, seja ela literária ou fílmica. De acordo com Umberto Eco,

Temos science fiction como gênero autônomo quando a especulação contrafactual de um mundo estrutu-

\footnotetext{
7 Essa Ficha Descritivo-Analítica está fornecida no artigo "STAR TREK - Deep Space Nine na sala de aula - Filosofia, política e alteridade na vizinhança do wormhole", publicado na REVISTA ESTUDOS DE FILOSOFIA E ENSINO, v. 1, n. 1, 2019
} 
ralmente possível é conduzida extrapolando, de algumas linhas de tendência do mundo real, a possibilidade mesma do mundo futurivel. Ou seja, a ficção científica assume sempre a forma de uma antecipação, e a antecipação assume a forma de uma conjetura formulada a partir de linhas de tendência reais do mundo real". (ECO, 1989, p. 169)

Para ele, a boa ficção científica não é a que apresenta prodígios tecnológicos, laboratórios e seus aventais, mas a que discorre sobre a conjecturabilidade da ciência e seus produtos. A extrapolação científica e tecnológica baseia-se, então, na racionalidade científica e obedece a elementos do próprio pensamento científico e à disposição mental correlata. Como afirma Piassi (2013, p. 162), "a construção do discurso da ficção científica, através da derivação, é pautada, a nosso ver, por uma conjecturabilidade que se inscreve dentro dos limites de uma racionalidade lógico causal pautada pela exploração dos efeitos humanos decorrentes da colocação do leitor em frente ao novum". Essa ponderação também vale para o espectador, porque o novum, por sua vez, tem a possibilidade de provocar conjecturas sobre os efeitos sociais, políticos, ambientais, morais daquilo que é apresentado pela diegese da obra de scifi.

A característica central de uma obra de ficção científica é o modo peculiar como a ficção e a ciência são correlacionadas, uma vez que esta última, na narrativa ficcional, necessita estar à frente da realidade atual $e$ extrapolar os dados científicos do tempo presente, contudo, dentro da plausibilidade daquilo se tornar real. (FIKER, 1985; ALLEN, 1973) Entretanto, como recorda Tucherman
(2003), a ficção científica não possui os compromissos que a ciência possui e nem se submete às provas de verificação, comprovação, falsificação.

O século XIX nos legou a obra de Mary Shelley, Frankenstein, ou o moderno Prometeu (1818), em que a autora, ao narrar as histórias do médico Victor Frankenstein e de sua Criatura, pela primeira vez questionou as consequências do uso da ciência moderna numa obra ficcional. Posteriormente, os escritores Júlio Verne $e^{8}$ e H. G. Wells ${ }^{9}$ influenciaram decisivamente, cada um à sua maneira, o rumo da literatura de ficção científica. Na década de 1920, o editor Hugo Gernsback foi o responsável pela edição $e$ disseminação de obras de sci fi em papel jornal, voltadas para o público popular, através da revista Amazing Stories, especialmente formado por jovens e que foram vendidas nas bancas de jornais. Na década de 1940, John W. Campbell, cravou seu nome na história da ficção científica ao editar a revista Astounding Stories (Histórias Aterradoras). No cinema, coube a George Méliès a primazia da realização de um filme de sci fi, Viagem à Lua (1902), que narra a história da chegada de humanos na Lua. Das bancas de jornais e do primeiro cinema a ficção científica tomou a forma de diferentes produtos como livros, histórias em quadrinhos, filmes, séries televisivas, desenhos animados, animes, mangás, e mais recentemente, RPG (jogos de interpretação de papéis) e jogos eletrônicos. Ela tornou-se, pois, um produto importante da cultura de massa que incorpo-

\footnotetext{
8 Viagem ao centro da Terra (1863), Da Terra à Lua (1865), dentre outras obras

${ }^{9}$ A máquina do tempo (1895), A Ilha do Doutor Moreau (1896) e O homem invisivel (1897), dentre outras obras
} 
ra diferentes segmentos sociais, públicos consumidores, mídias e narrativas transmidiáticas.

Em sala de aula, textos fílmicos (inclusive os das séries televisivas) de sci-fi mostraram-se, na minha prática docente, como documentos válidos que permitiram problematizar com os estudantes a ciência $e$ a tecnologia e outros temas, porque manifestam o imaginário social contemporâneo. Para tanto, utilizo nos debates as reflexões de G. Durand $^{10}$ (2002) e de B. Baczko ${ }^{11}$ acerca do imaginário e do imaginário social. Ambos indicam a existência da dimensão simbólica da imaginação como estruturante da realidade, uma vez que apontam para a existência de rede de significações imaginárias estabelecidas pelo indivíduo e por grupos sociais e que define o que é real ou não, tem sentido ou não. Os textos fílmicos como documentos informacionais são, por um lado, portas que conduzem ao imaginário social em que a tecnologia se faz presente, que desvelam modos como a tecnociência e seus produtos são assimilados na nossa cultura, $e$

10 G. Durand explicou que a imagem consiste na matéria de todo processo de simbolização e o imaginário expressa a capacidade humana, individual $e$ coletiva, de dar significação ao mundo e a tudo que há.

${ }^{11}$ B. Baczko elaborou reflexão acerca do imaginário social e destacou a existência de formas particulares, em cada período histórico, de imaginar, sentir, acreditar, pensar específicos que manifestam naquilo que uma coletividade produz materialmente. Enquanto rede imaginária se expressa por meio de ideologias, utopias, símbolos, alegorias, rituais e mito. Sua atuação elabora visões de mundo e molda comportamentos, condutas, estilos de vida; também age como forma de controle da vida coletiva, do exercício da autoridade e da legitimidade do poder e, nesse sentido, funciona para a coesão e consentimento sociais. podem inspirar a produção tecnocientífica ${ }^{12}$. Por outro, eles se revelam também como motivadores da reflexão e da aprendizagem, uma vez que os textos fílmicos de sci-fi apresentam questões sociais, políticas, ambientais e morais relacionadas ao desenvolvimento técnico-científico; e, igualmente, são bons instrumentos para provocarem o questionamento filosófico sobre o ser humano, seu agir sobre a realidade na circunstância de seu encontro com a alteridade. Nesse sentido, desde a segunda metade do século XIX o grande desenvolvimento da moderna tecnociência gerou obras que fizeram da ciência e da técnica os aportes necessários para o desenvolvimento de tramas ficcionais, ora distópicas, ora utópicas, relacionadas ao incremento científico e à vida comum

Desse modo, a perspectiva norteadora das pesquisas realizadas e da prática pedagógica que as ensejou é que os produtos ficcionais (obras literárias, filmes, séries, jo-

12 Sobre esse fato há uma interessante fala de George Takei, o eterno capitão Sulu: "Faz 40 anos desde a época em que filmamos o segundo piloto que vendeu Jornada nas Estrelas, e ainda assim a série me parece muito atual. Nos anos 1960, as questões que confrontavam a sociedade eram guerra $e$ paz, corrupção $e$ integridade, preconceito e idealismo, e força vindo da diversidade. [...] Gene Roddenberry, o criador de Jornada, era um verdadeiro visionário. Tanto do que era apresentado como ficção científica e tecnologia especulativa acabou se tornou realidade em 40 anos. Aquele incrivel aparelho de ficção científica que chamávamos de "console", reconhecemos hoje como o nosso computador do dia-a-dia. Aquele aparelho, "oh uau!", que usávamos na cintura e abríamos para falar com alguém em qualquer lugar era a mesma coisa que hoje chamamos de telefone celular. Hoje, temos robôs perambulando pela superfície de Marte. Hoje, temos uma nave espacial com uma tripulação composta por pessoas de todos os continentes deste planeta. Até russos e americanos trabalhando lado a lado, como em Jornada nas Estrelas". (NOGUEIRA, 2005) 
gos, HQs, mangás, imagens, dentre outros) de uma dada cultura são peças que revelam o imaginário social dessa sociedade. Por conseguinte, filmes e séries televisivas ao dramaticamente apresentarem a ciência e a tecnologia inseridas em contextos socialmente significativos se mostraram como dispositivos relevantes para a discussão de temas abordados com os estudantes, seja porque motivam o pensamento criativo, seja porque contribuem para o desenvolvimento das habilidades de reflexão, argumentação e de escrita.

O uso pedagógico de tais recursos não pretendeu ensinar ciência ou tecnologia, mas abordar de maneira histórico-filosófico as implicações sociais, no sentido amplo do termo, do desenvolvimento das ciências e da tecnologia, com o fito de possibilitar a reflexão sobre o presente que redunda na ação sobre o futuro.

Filosofando com a tradição e com a narrativa sci fi de Deep Space Nine

Nesse segmento vou expor aspectos da minha experiência com a conjugação de episódios de Star Trek Deep Space Nine com a discussão filosófica.

Dentre os produtos indústria cultural fez história o seriado de TV Star Trek (Jornada nas Estrelas), que lançou os humanos no Espaço, a Fronteira Final e narrou os encontros e desencontros de diferentes seres vivos, que tiveram a mítica nave espacial USS Enterprise NCC-1701 como instrumento catalizador. Gene Roddenberry criou o projeto Star Trek e entre 08 de setembro de 1966 a 03 de junho de 1969 foram apresentados os episódios daquela que é conhecida como a Série Clássica de Star Trek (TOS The Original Serie).

Suas histórias se passam entre os anos 2265 e 2270 e narram as aventuras da tripulação liderada pelo mais jovem capitão da Frota Estela, James T. Kirk, que comanda a USS Enterprise NCC1701, sempre em viagem em busca de novas formas cultura e de novas experiências. Na série original apareceram os primeiros personagens fixos da narrativa de ficção científica televisiva, conforme o conceito desenvolvido por Gene Roddenberry, na década de 1960. Os episódios mostram a realidade de um futuro situado no século 23, em que os terráqueos e a Terra fazem parte da Federação dos Planetas. Por gozarem da vida sem conflitos ou problemas sociais, eles podem se dedicar a se aventurar pelo desconhecido para ampliar o conhecimento sobre diferentes civilizações A já mítica USS Enterprise seria marcada pela diversidade de seus membros, que contava com um oriental (o timoneiro Sulu), uma oficial de comunicações negra (tenente Uhura, que foi a única mulher a trabalhar permanentemente na Ponte de Comando $e$ também em campo), um russo (o navegador Pavel Chekov), um alienígena de Vulcano (Spock), e também o médico McCoy, o engenheiro Montgomery Scott e o emblemático capitão Kirk. A primeira diretriz obrigatória da Enterprise era o respeito a diferentes patamares de evolução civilizatória, que levou o capitão e sua tripulação a não intervirem nos processos evolutivos das civilizações encontradas.

A Série Clássica está na origem de Star Trek - Deep Space Nine, que estreou em 1993. Essa spin-off teve sete temporadas, 176 episódios distribuídos e foi encerrada 
em 1999. Ao contrário das demais séries Star Trek que se passaram na USS Enterprise, a quarta franquia transcorreu na base espacial estacionada Deep Space Nine, antiga base mineradora cardassiana Terok Nor (também conhecido como Base Espacial Nove).

Na percepção da crítica especializada e de fãs, DS9 é a série trek que mais se afastou da possibilidade de ter sido uma reprise do formato deixado pela Série Clássica. Numa entrevista Michael Piller, um dos criadores e roteiristas, explicou que ao longo dos episódios foi possível "confrontar os valores humanistas de Roddenberry com os valores espirituais e metafísicos dos alienígenas", a fim de explorar novas ideias e tensionar situações. (Nogueira, 2001)

Para os que não conhecem $D S 9$ tornase necessária breve síntese em aspectos gerais do enredo de DS9: o comando da Frota Estelar deu a Benjamin Sisko ${ }^{13}$, em 2369, o comando da estação de mineração cardassiana Terok Nor que estava em órbita do planeta Bajor. Os cardassianos do planeta Cardássia ocuparam, subjugaram e exploraram violentamente o planeta Bajor e os bajorianos. As histórias narradas da DS9 se passaram, portanto, no contexto da saída dos cardassianos de Bajor. Sob a liderança do antigo comandante de Terok Nor, Gul Dukat, os cardassianos abandonaram e destruíram a estação, quando se retiraram dela e também do planeta ocupado. Para complicar a situação já confusa, Sisko foi saudado pela líder religiosa bajoriana kai Opaka como um Emissário, ou seja, como uma espécie de avatar da religião de Bajor e caberia a ele

\footnotetext{
${ }^{13}$ Benjamin Sisko foi o primeiro negro a ocupar o posto de oficial comandante na franquia Star Trek.
}

encontrar o Templo Celestial, o lar dos deuses dessa religião e contatar as divindades chamadas de "Profetas". Em sua missão de busca dessas entidades, Sisko encontrou uma fenda espacial estável nas fronteiras de Bajor; ao entrar nela contatou seres que lá viviam numa peculiar temporalidade que não distinguia passado, presente, futuro. Sisko foi devolvido à vida pelos Profetas que permitiram que outras naves cruzassem a fenda para comércio e exploração. Esta ação transformou o status de Bajor e a estação DS9 numa estratégica parada obrigatória para quem chegasse até aquele ponto de ligação com o Quadrante Gama. Um ano depois de sua chegada à estação, Sisko tomou conhecimento do Dominion ${ }^{14}$ ao ser preso por soldados Jem'Hadar. Uma situação de guerra se estabeleceu com os Fundadores Transmorfos ${ }^{15}$ do Dominion, que formam um povo que não é sólido e que se realiza no Grande Elo. Eles temem os seres vivos sólidos e por isso tentam se proteger ao dominá-los. Na sequência dos acontecimentos, Sisko começou a acreditar que poderia realmente fazer parte da mitologia barjoriana até que, finalmente, assumiu seu papel como Emissário. Nesta função ele encontrou a sagrada cidade bajoriana de B'Hala Por fim, Sisko terminou por se juntar aos Profetas no Templo Celestial ao desaparecer nas caver-

\footnotetext{
${ }^{14}$ Os Fundadores Dominion são os responsáveis pela criação de duas raças geneticamente modificadas, criadas para servi-los: os vorta (os diplomatas) e os Jem'Hadar, que formam suas tropas guerreiras e protetoras.

${ }^{15}$ Shapeshifter. termo genérico aplicado a espécies de seres vivos que podem alterar suas formas e assumir diferentes aparências. Os Fundadores Dominion, o povo de Odo, são shapeshifters ou metamorfos (ou transmorfos) que, por não serem sólidos, podem assumir inclusive formas humanoides.
} 
nas de fogo, em 2375. A Primeira Oficial da estação Terok Nor ou DS9 foi a bajoriana Kira Nerys, responsável por fazer a ligação entre Bajor e a Federação. Antes guerrilheira durante a opressão cardassiana, entendeu a importância da Federação para a proteção de Bajor no contexto do planeta estar no limite da importante fenda espacial. No final de sua história, terminou como comandante da estação Deep Space Nine, após o desaparecimento de Sisko. Outra personagem relevante é o metamorfo (ou transmorfo) Odo $^{16}$, descoberto no Cinturão Denórios, no sistema bajoriano.

A Base Espacial Nove é um pequeno mundo onde as diferenças políticas, econômicas, religiosas, culturais, enfim, se encontram radicalmente. Por isso, há certa unanimidade entre os trekkers que DS9 é a jornada mais política, conflituosa, dark da franquia. Ao contrário das demais séries, as histórias se passam dentro de uma base estacionária e não numa nave, fato que agudiza os conflitos existentes naquela comunidade. Presos na Estação Nove, é impossível viajar pelo espaço, de um quadrante a outro, contatar civilizações, ao final se afastar, e voltar à vida conhecida. Aqueles que estão na base espacial vivem cotidianamente os dramas da dificuldade de lidar com as diferenças e com diferentes perspectivas de vida. La estão terráqueos, cardassianos, bajorianos, simbion-

\footnotetext{
16 Odo atuou como Oficial Chefe de Segurança da estação cardassiana Terok Nor e, posteriormente, da estação bajoriana Deep Space Nine. No final da história, após o término dos conflitos entre o Dominion e a Federação e seus aliados retornou ao Grande Elo para curar seu povo de uma praga desenvolvida pela Seção 31 e para ensinar aos Fundadores transmorfos como lidar com as formas de vida sólidas.
}

tes, trills, klingons, ferengis, metamorfos Dominion, humanos mudados geneticamente e toda uma fauna ampliada de diferentes raças. Como explicou Lee,

Star Trek: Deep Space Nine abriu novos caminhos na complexidade $e$ ambiguidade moral de seus personagens e de suas situações. Com sua descrição madura dos efeitos posteriores da ocupação brutal de Bajor pelos cardassianos, a série conseguiu lidar com questões de justiça transicional similares àquelas levantadas no pós-Holocausto, o final do Apartheid e do governo branco na África do Sul e a queda do comunismo no Leste Europeu, para citar alguns. (LEE, 2010, p. 123)

Provavelmente os maiores obstáculos e dificuldades enfrentadas decorrem dos 60 anos de ocupação brutal de Bajor por Cardássia, que geraram uma complexa e frágil situação política, dores, ressentimentos. Para evitar que os cardassianos voltassem a subjugar os bajorianos, a Federação foi convidada a administrar a Estação Nove junto com o governo provisório de Bajor. Por outro lado, a posição estratégica da estação, nas vizinhanças do buraco de minhoca, provocou grande afluência de indivíduos de diferentes culturas planetárias e a difícil convivência entre eles, por não compartilharem os valores da Federação e nem os de Bajor. Essas diferenças foram desenvolvidas pelos roteiristas, fato que ampliou muito os conflitos, daí as tintas da série que muitos trekkers consideram, no geral, como pesadas, sombrias. Por conseguinte, aquele tom utópico de encontro de culturas está bem longe do cotidiano de DS9. Nas histórias narradas nos episódios com frequência são encontradas 
abordagens morais de situações que envolvem conflitos e/ou diferenças raciais, religiosas, de gênero e de guerra. Como explica Eduardo Roth,

E qualquer espectador mais atento consegue perceber que as metáforas $e$ analogias com o "mundo real" mostrados em Deep Space Nine são muito mais claros e gritantes do que nas suas séries antecessoras. Israelenses e Palestinos, Cardassianos e Bajorianos. Fanatismo religioso. Manipulação das massas e engenharia social. Militarismo. Capitalismo canibal. Sexismo. Corrupção política e institucional. Terrorismo. Apropriação cultural. Temas que continuam atuais, passados vinte e dois anos da estreia da série. (ROTH, 2015, s/p)

O otimismo presente no ideário da Federação de Planetas Unidos em relação ao encontro com outras culturas e ao progresso em DS9 colide com o tensionamento radical desse ideário nas narrativas que apresentam experiências atravessadas pela religião e religiosidade e seu conflito com as ciências, pelo encontro difícil com o diferente, pela tortura e exploração extrema de povos, pelo ódio, pelo colaboracionismo, pelas regras comerciais. Como as personagens vivem numa Estação Espacial estacionada, reiteradamente precisam conviver com as consequências de suas ações. $\mathrm{O}$ encontro com a alteridade é exposto por meio do exame das relações diplomáticas, religiosas, científicas, sócioeconômicas e militares desenvolvidas especialmente por cardassianos, bajorianos, transmorfos, ferengi e a Federação. Nessa perspectiva, com frequência esteve em pauta a discussão sobre o que vem a ser terráqueo, cardassiano, bajoriano, fato que está muito além das diferenças físicas.

Passo a seguir indicar um exemplo de como, em disciplinas, utilizei Deep Space Nine e textos filosóficos para discutir o encontro com o diferente. Para situar os estudantes na série solicito que assistam os dois primeiros episódios, $O$ emissário - partes I e II, e também Dueto, que será o objeto de discussão para analisar essa relação com o outro em diálogo com dois ensaios de Montaigne (Sobre os canibais e Sobre os coches) e Micrômegas, o conto filosófico de Voltaire.

$\mathrm{O}$ pano de fundo dos ensaios que utilizo é a "descoberta" daquele que foi chamado pelos europeus de novo mundo. Esse contexto permite a preparação do terreno para a posterior discussão, no âmbito do desenvolvimento temático da disciplina, do encontro com o outro pelo olhar da colonialidade, tal como elaborada por Aníbal Quijano, que no recorte desse artigo não será possível abordar.

A imagem fechada e estável do Velho Mundo foi quebrada por esse encontro, que foi narrado por seguidas edições, tamanho o interesse suscitado, de obras como as de André Thévet ${ }^{17}$, Jean de Léry ${ }^{18}$, de Hans Staden $^{19}$, de Bartolomeo de las Casas ${ }^{20}$ ou as crônicas de Gonzalo Oviedo e de Francisco López de Gómara ${ }^{21}$, aforas as gravuras com cenas da vida dos povos encontrados, especialmente as cenas de canibalismo. Pela perspectiva do velho mundo aquele era, sim,

\footnotetext{
17 As singularidades da França Antártica (1557).

18 História de uma viagem feita à terra do Brasil (1578).

${ }^{19}$ Duas viagens ao Brasil (1557).

20 O Paraíso Destruído: brevíssima relação da destruição das Índias (1552)

${ }^{21}$ Historia General de las Indias (1552).
} 
um mundo novo descoberto, conforme o próprio Montaigne, em pleno século XVI, reconheceu. No ensaio Sobre os coches constatou

Nosso mundo acaba de encontrar um outro [mundo] não menor, nem menos povoado e organizado do que o nosso (e quem nos diz que seja o último?), e no entanto tão jovem, que ignora o a-bê-cê [...]. Receio porém, que venhamos a apressar a decadência desse novo mundo com nosso contato e que ele deva pagar caro nossas artes e ideias. (MONTAIGNE, 1987-88, p. 136137)

E o próprio filósofo lamentou as possíveis consequências do encontro. Nesse ensaio encontramos a narrativa de possibilidades do encontro com o diferente, sua destruição física ou sua redução (subsunção) ao que somos. Ele descreveu a destruição dos impérios astecas e maias, a escravização e a exploração das populações nativas:

Ao contrário só tiveram diante deles [os espanhóis] exemplos de desregramentos e abusos. Aproveitamonos de sua ignorância e inexperiência e lhes ensinamos a prática da traição, da luxúria, da avareza; e os impelimos aos atos de crueldade $e$ de inumanidade. Ter-se-á jamais perpetrado tanto crime em nome do comércio? Quantas cidades arrasadas, quantos povos exterminados! Milhões de indivíduos trucidados, em tão bela e rica parte do mundo, $e$ tudo por causa de um negócio de pérolas e pimenta! Miseráveis vitórias! Nunca a ambição incitou a tal ponto os homens a tão horríveis $e$ revoltantes ações! (MONTAIGNE, 1987-88, p. 137)
Esses fatos imediatamente são relacionados ao violento domínio e escravização dos bajorianos pelos cardassianos para a manutenção da expropriação dos recursos do planeta Bajor e a análise de outros exemplos históricos sempre são apresentados pelos estudantes.

No ensaio Sobre os Canibais foi relatada uma fictícia conversa do rei francês com três indígenas brasileiros que teriam tomado parte do cortejo em homenagem ao adolescente rei Carlos IX, em Rouen. O ensaísta mesclou um acontecimento histórico (a entrada de Carlos IX em Bordeaux, em 1565) a partes ficcionais. A partir dessa ficção filosófica, Montaigne, discorreu sobre a relatividade das culturas e, sob o ponto de vista dos "canibais", criticou o descaso da corte francesa para com os pobres. Nesse ensaio foi também apresentada a figura do bom selvagem, do indivíduo puro e não corrompido pela cultura europeia. Esse filósofo foi um dos que, em seu tempo, elogiou a vida natural dos nativos do Novo Mundo ao relativizar, por meio de seu relato sobre aspectos da cultura e da sociedade indígenas, a opinião de muitos que os apresentavam como bárbaros, intelectual e moralmente inferiores aos europeus, e finalizar o ensaio com as "observações canibais" acerca da política e da injustiça social reinante na Europa. Em sua narrativa relativizou o sentido de bárbaro; para os gregos foram bárbaros os não gregos; para os romanos, aqueles que não tinham a romanitas. Como afirmou Montaigne, "não vejo nada de bárbaro ou selvagem no que dizem daqueles povos; e, na verdade, cada qual considera bárbaro o que não se pratica em sua terra. E é natural, porque só podemos julgar da verdade e da razão de 
ser das coisas pelo exemplo e pela ideia dos usos e costumes do país em que vivemos". (MONTAIGNE 1987, p. 101) Em sua ficção ensaística descreveu longamente os costumes dos nativos das terras brasilis como a organização social, poligamia, o gosto pela guerra por orgulho, a antropofagia, aspectos que muito chamou a atenção dos europeus. Ao fim e ao cabo argumentou que, no mínimo, se os indígenas eram bárbaros por serem cruéis canibais, os europeus desenvolvidos e requintados também o eram, uma vez que esses, dentre outras práticas, dilaceravam corpos dos que consideravam diferentes ou inimigos com martírios e tormentos, assava-os vivos lentamente ou os atirava vivos a cães e a porcos; e reconheceu que os europeus, de fato, excediam no quesito barbárie qualquer nação indígena.

No saboroso conto filosófico Micrômegas Voltaire lançou mão do relato de viagem para narrar a excursão realizada por personagens extraterrestres entre mundos intergalácticos. A peça literária é propícia, por um lado, para desvelar o estranhamento dos gigantes Micrômegas e seu companheiro de viagem ao chegarem a mundos desconhecidos e diferentes, tal como a Terra. Por outro, o autor usou o olhar de alienígenas para criticar costumes e tabus sem grandes preocupações e também para tornar visíveis absurdos que são invisíveis no mais das vezes. Nesse sentido ele aproveitou a figura do estrangeiro como artifício literário para sua própria expressão filosófica. O conto filosófico narra a história do jovem gigante Micrômegas, habitante da estrela Sirius, de 450 anos, que resolve viajar pela Via Láctea para conhecer povos e costumes. Como companheiro de viagem teve um "anão" do plane- ta Saturno, que batia na altura de suas pernas. Chegaram à Terra e com muito custo conseguiram perceber minúsculos seres falantes terráqueos, dentre os quais pequeninos filósofos com quem conversaram. Ao longo dos diálogos ficaram desconcertados quando descobriram que aqui sempre se almejava mais, à custa de massacres. Os viajantes compreenderam que aqui viviam seres com consciência e linguagem, que se sentiam geniais e que provocaram risos nos gigantes por causa das disputas filosóficas acirradas diante das perguntas feitas pelos extraterrestres, pois esses não entendiam como seres tão minúsculos poderiam ter tamanha pretensão e arrogância. Nesse sentido, o conto de Voltaire é um convite para a escuta e entendimento sem preconceito do outro, mesmo que diferente e estranho, e para a abertura a diferentes perspectivas e ângulos de visão.

As reflexões de Montaigne e Voltaire estão marcadas pelas viagens que alcançaram o Novo Mundo e que reconfiguraram o processo de se deparar com o outro no alvorecer da modernidade. Esse encontro significou, no mais das vezes, a destruição dos povos que habitavam os territórios, a destruição de culturas, de línguas, de cosmologias, saberes e sistemas de conhecimento, mediante a imposição colonial do sistema europeu de conhecimento e sua lógica. (Quijano, 2010); significou também que o fim do mundo chegou no século XVI para incontáveis etnias da terra brasilis, como afirmou Ailton Krenak (2019).

É justamente a dificuldade presente no encontro com a alteridade e também o absurdo de ver o outro com as prerrogativas 'do mesmo' que procuro discutir, mediante o 
recurso de textos filosóficos e textos fílmicos, com estudantes universitários.

Na Estação Espacial Nove, o comandante Sisko entendeu que muitos dos dilemas e problemas que ele enfrenta no cotidiano da Estação Nove decorrem da Terra,

SISKO - O real problema é a Terra. $\mathrm{Na}$ Terra não existe pobreza, crimes nem guerra. Você olha pela janela do quartel-general da Frota Estelar e vê o paraíso. Bem, é fácil ser santo no paraíso, mas os Maquis não vivem no paraíso. Lá, na zona desmilitarizada, todos os problemas ainda não foram resolvidos. Lá, não há santos, apenas pessoas - pessoas com raiva, com medo, determinadas, que farão o que precisarem para sobreviver, com ou sem a aprovação da Federação. (episódio Os Maquis - parte II, 1994)

Essa fala demonstra também como Deep Space Nine deixou à mostra as fraturas na utopia idealizada da franquia: a Federação também não é lugar de santos ${ }^{22}$. Como argumenta Marnie Nolton, Sisko compreendeu que "não há soluções fáceis para as complexidades da vida na DS9 e em torno dela". (NOLTON, 2010, p. 207) E também que as ações da Federação eram ambíguas e iam da faceta de defensora de indivíduos, povos e planetas ao oportunismo para man-

$22 \mathrm{O}$ arco narrativo dos Maquis, que atravessa diferentes episódios, mostra como vários oficiais da Frota Estelar desconfiaram das intenções da Federação e se voltaram contra ela, ao unirem-se aos Maquis, quando perceberem que muitas vidas foram sacrificadas para que a Terra continuasse a ser o lugar paradisíaco. Os Maquis são grupos de cidadãos da Federação, incluídos oficiais, que se colocaram contra a própria Federação por serem obrigados a sair de suas casas devido ao acordo entre a Federação e Cardássia. ter a estabilidade e a segurança da fenda espacial, que abria potenciais oportunidades, mesmo que a custa da vida dos Maquis, por exemplo.

Comentarei sucintamente aspectos o episódio Dueto, um dos mais tensos e intensos da série e sempre presente nas listas dos melhores de DS9 e também de Star Trek, porque nele ressoa a vida emocional dos personagens e além disso, a abordagem política e histórica. O roteiro desenvolve a história sem subtramas e se concentra no jogo moral desenrolado entre Kira Nerys e um (suposto) responsável por hediondos crimes de guerra ${ }^{23}$ perpetrados contra o povo dela.

A história gira em torno de Kira Nerys, do genocídio, da justiça e do justiçamento A oficial imediata do capitão Sisko teve papel relevante na libertação de seu povo do jugo cardassiano e conheceu bem de perto os efeitos da brutalidade de Cardássia, pois, na resistência, ajudou a libertar os trabalhadores prisioneiros do campo Gallitep. Por isso, dependendo do enfoque, para uns ela foi libertadora e para outros, suas ações beiraram a de uma terrorista. A narrativa inicia quando um cargueiro atracou na base para que dos passageiros pudesse receber tratamento para uma síndrome bem específica, Kalla-Nhora. Esse mal, causado por um acidente de mineração, afetou aqueles que estavam num brutal campo de trabalho cardassiano, Gallitep. O doente, Aamin Marritza, era cardassiano e Kira Nerys o prendeu por crime de guerra. Entretanto, o nome de Marritza não aparecia relacionado a algum

\footnotetext{
${ }^{23} \mathrm{O}$ tema da guerra e de suas consequências é recorrente em DS9.
} 
crime e o comandante Sisko mandou soltálo. A oficial insistiu em mantê-lo preso. Ao continuar a investigar, descobriu por uma foto, que aquele era Gul Darhe'el, conhecido como o "açougueiro de Gallitep", por ter assassinado milhares de bajorianos. No interrogatório, o prisioneiro admitiu orgulhosamente ser Darhe'el e confrontou a oficial. Porém, a história contada por ele tinha muitas inconsistências para ele fosse realmente quem dizia ser. O médico da estação descobriu, ademais, que o homem passou por inúmeras cirurgias estéticas, fato que levou à conclusão de que ele era, de fato, Marritza, o arquivista, que se passava por Gul Darhe'el, considerado herói entre seu povo. Ao ser questionado quanto aos motivos de assumir outra identidade, o arquivista, atormentado pelo remorso e pela percepção dos crimes cometidos por Cardássia, revelou que acompanhou todas as atrocidades sem coragem para se opor, por covardia e medo; com o tempo desejou a justiça para todos que pereceram em condições atrozes. Na pele de Darhe'el pretendeu forçar Cardássia a admitir os erros e as atrocidades e dar a Bajor a satisfação de julgar um criminoso de guerra. No final, ao ser escoltado de volta ao navio, Marritza foi esfaqueado fatalmente. Ao buscar entender a motivação para aquele ato criminoso, o bajorano disse à oficial que aquele homem assassinado era um cardassiano e esse era motivo suficiente para matálo. Kira Nerys percebeu amargamente a tragédia das danças dançadas a dois por ódio $e$ ressentimento, por violência e covardia; compreendeu a extensão da injustiça e da perversão que rondam o ódio de raça, e/ou a exploração e reificação de um povo por outro, e/ou o justiçamento.
Um dueto consiste no encontro de duas pessoas. $\mathrm{O}$ encontro com o outro é aspecto central na Estação Nove. Em verdade, a alteridade sempre esteve presente no universo Star Trek. A primeira diretriz da Federação apontava já para o encontro com o outro. Nas histórias das diferentes Jornadas, suas Enterprise, tripulações e capitães, o encontro e o embate com o outro, por mais dramático que fosse sempre terminava em um episódio ou ao fim de um arco narrativo. Mas na Estação Espacial Nove as dificuldades dos variados duetos, uns mais outros menos conflitantes, marcam o cotidiano daquela comunidade encravada na beira do wormhole. Na narrativa do episódio Dueto de modo particular há o encontro de Kira Nerys com o arquivista Marritza/Gul Darhe'el e de Marritza com Darhe'el, na pele do próprio arquivista. Ao longo da trama ressoam questionamentos sobre os efeitos profundos da guerra e do genocídio pela perspectiva do oprimido e do opressor, sobre a covardia, a vingança e a justiça, sobre a necessidade de auto-reconhecimento individual e do reconhecimento dos erros e crimes coletivos cometidos por um povo para que assim possa iniciar uma nova história, sobre o perdão e o sacrifício. Esses elementos constroem as vozes e as ações do comandante Sisko, de Gul Dukat e Marritza, de Cardássia, de Kira, de Bajor. No fim do episódio permanecem as perguntas pelos monstros e suas monstruosidades cometidas contra o diferente, pelo preconceito que mata e pelo justiciamento decorrente do preconceito, da vingança e do ódio.

\section{Considerações finais}


O objetivo desse artigo foi apresentar aos leitores o cerne do método analíticointerpretativo de filmes que foi desenvolvido em pesquisas sobre as possibilidades da pedagogia da imagem. Foi explicado porque filmes e séries televisivas são consideradas, por um lado, como texto fílmico, ou seja, um objeto delimitável que materializa o discurso cinematográfico, o qual comporta, por sua vez, diferentes códigos cinematográficos $e$ não-cinematográficos. Igualmente são compreendidos, por outro lado, como documento informacional, i.e, como um espaço onde estão inscritas informações que dão forma a conteúdos que podem, mediante análise, alcançar estruturas, metáforas, alegorias, símbolos constitutivos do imaginário social. Foram abordados também os três níveis de informações que constituem o filme como documento informacional e que são agenciados pelos espectadores/leitores na prática pedagógica.

Igualmente foi mostrado como essa metodologia favorece a utilização de filmes $e$ séries televisivas em sala de aula de modo crítico, pois permite a identificação de estruturas, contextos, metáforas, alegorias e sinais que manifestam aspectos do imaginário da sociedade e da sociabilidade, especialmente a contemporânea.
Por fim, foram também expostos aspectos teóricos que embasam o modo como são debatidos alguns temas com estudantes, a partir da utilização do exemplo do conteúdo ministrado em disciplina acerca do encontro com outro (alteridade) no âmbito do contexto político, e que conjugou textos filosóficos e texto fílmico na prática de ensino de filosofia. Optou-se por apresentar recortes do exercício feito durante os debates sobre esse tema, e para tanto foram selecionados como textos filosóficos dois ensaios de Montaigne, o conto filosófico de Voltaire (Micrômegas) e o artigo de A. Quijano sobre colonialidade, sendo que esse último não foi possível ser abordado. A narrativa fílmica escolhida foi o episódio Dueto da primeira temporada de Deep Space Nine. Nesse sentido, foram entrelaçadas a tradição filosófica, a ficção científica e o dramático e trágico encontro do Velho Mundo com o Novo Mundo mediante a chegada dos europeus às Américas.

\section{Referências}

ALLEN, D. No mundo da ficção científica. São Paulo: Summus, 1973.

BACZKO, B. "Imaginação social". In: Enciclopédia Einaudi. Disponível em: https:// drive.google.com/drive/folders/0B2fYI0opdjTIWFYtNVVZQTc4eUU. Acesso: 28 set. 2015.

CARRIÉRE, J-C. A linguagem secreta do cinema. Rio de Janeiro: Nova Fronteira, 1995.

DURAND, G. As estruturas antropológicas do imaginário. São Paulo: Martins Fontes, 2002. 
. O imaginário: ensaio acerca das ciências e da filosofia da imagem. Rio de Janeiro:

Difel, 1998.

ECO, U. Sobre os espelhos e outros ensaios. Rio de Janeiro: Nova Fronteira, 1989.

FIKER, R. Ficção Científica: ficção, ciência ou uma épica da época? Porto Alegre: L\&PM, 1985.

FLUSSER, V. Filosofia da caixa-preta: ensaios para uma futura filosofia da fotografia. São Paulo: Relume Dumará, 2002. me, 2010.

O universo das imagens técnicas: o elogio da superficialidade. São Paulo: Annablu-

JENKINS, H. Cultura da convergência. São Paulo: Aleph, 2009.

JOST, F. Do que as séries americanas são sintoma. Porto Alegre: Sulina, 2012

KRENAK, A. Ideias para adiar o fim do mundo. São Paulo: Companhia das Letras, 2019

MONTAIGNE, M. de. Sobre os Canibais. In: Ensaios. Disponível em: http:// www.ufscar.br/ igor/wp-content/uploads/mont.pdf. Acesso em: 10 jul. 2017

. Sobre os coches. In: Ensaios. Disponível em: https://www.companhiadasletras.

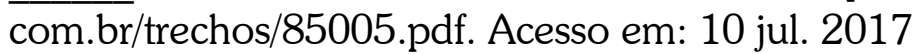

QUIJANO, A. Colonialidade e Modernidade/Racionalidade. 2010. Tradução de Wanderson Flor do Nascimento. Disponível em: https://www.buenastareas.com/ensayos/Colonialidade-eModernidade-Racionalidade-An\%C3\%ADbal-Quijano/1214755.html. Acesso em: 10 jul. 2017

VOLTAIRE. Micrômegas. Disponível em: http://ivros01.livrosgratis.com.br/cv000044.pdf. Acesso em: 20 mar. 2017

NOGUEIRA, S. Michael Piller: a modernidade da Jornada. 2001. Trek Brasilis. Disponível em: https://www.trekbrasilis.org/classico/entrevistas/entrevista8.htm.Acesso em: 03 de janeiro de 2001.

Duas vezes George Takei. 2005. Trek Brasilis. Disponível em: <https:// www.trekbrasilis.org/classico/entrevistas/entrevista18.htm >. Acesso em: 03 de jan. de 2005

SILVA, M. Cultura das séries: forma, contexto e consumo de ficção seriada na contemporaneidade. Galáxia (São Paulo, Online), n. 27, jun.2014, p. 241-252. Disponível em: http://dx.doi.org/10.1590/1982-25542014115810

22 jul. 2016

MACHADO SILVA, J. As Tecnologias do Imaginário. Porto Alegre: Sulina 2003

WILKE, Valéria C. L., OLIVEIRA, Carmen I. C., RIBEIRO, Leila B. "Informação e texto fílmico: uma concepção de apropriação e uso de conteúdos informacionais em filmes de ficção". Comunicação apresentada no XXII Congresso Brasileiro de Biblioteconomia, Documentação e Ciência da Informação, Brasília, 2007.

. Didatizando o texto fílmico: uma proposta envolvendo concepções críticas de leitor e leitura. Revista Educação e Cultura Contemporânea, Unesa, v.6, 2009, p.109-121 
- "O filme como informação - a informação como processo transformador - a transformação do sujeito-espectador". ANAIS do Encontro Nacional da Associação de Pesquisa e Pós-graduação em Ciência da Informação e Biblioteconomia, Belo Horizonte. 2003. Disponível em: http://enancib.ibict.br/index.php/enancib/venancib/paper/viewFile/ 1937/1078.

. "O texto fílmico: suas leituras e práticas pedagógicas". ANAIS DA X COMPÓS, Brasília. 2001. Disponível em: <http://www.compos.org.br/data/biblioteca_1282.pdf>. Acesso em: 22 fev. 2003

Recebido em: 30/05/2020

Aprovado em: 22/10/2020 